\title{
Lectotypifications and new synonyms of Aristolochia (Aristolochiaceae) described by the Brazilian botanist João Barbosa Rodrigues
}

\author{
Joelcio Freitas ${ }^{1}$, Anderson Alves-Araújo ${ }^{1} \&$ Favio González $^{2}$ \\ ${ }^{1}$ Universidade Federal do Espírito Santo-UFES, Centro Universitário Norte do Espírito Santo-CEUNES, Departamento de Ciências \\ Agrárias e Biológicas, Rodovia BR 101 Norte, Km. 60, Bairro Litorâneo, São Mateus, ES, Brasil, CEP 29932-540 \\ joelciofr@gmail.com \\ ${ }^{2}$ Universidad Nacional de Colombia, Sede Bogotá, Facultad de \\ Ciencias, Instituto de Ciencias Naturales, AA 7495
}

\begin{abstract}
Freitas, J., Alves-Araújo, A., \& Favio González, F. 2016. Lectotypifications and new synonyms of Aristolochia (Aristolochiaceae) described by the Brazilian botanist João Barbosa Rodrigues. Anales Jard. Bot. Madrid 73(1): e030.

Taxonomic, nomenclatural and typification issues regarding Aristolochia chrysochlora Barb. Rodr., A. echinata Barb. Rodr. and A. silvatica Barb. Rodr. (Aristolochiaceae) are discussed. The lectotypes are designated based on the illustrations made by J. Barbosa Rodrigues, and published next to the corresponding protologues. Additionally, A. chrysochlora and $A$. echinata are subordinated to $A$. arcuata Mast., and $A$. tamnifolia (Klotzsch) Duch., respectively. We also designated the lectotypes for the latter two species.
\end{abstract}

Keywords: Brazil, João Barbosa Rodrigues, lectotypification, Piperales.

\section{INTRODUCTION}

With approximately 500 species, Aristolochia L. is the largest genus of the family Aristolochiaceae (González, 2011). The genus has a pantropical distribution and is highly diversified in the neotropics (González, 2000). In Brazil, 92 species of Aristolochia have been documented (Barros \& al., 2015), Brazil being one of the hotspots of the genus worldwide (González, 2000).

In the last two decades of the nineteenth century, several species were published in Brazil by J. Barbosa Rodrigues (1842-1909), an important Botanist who notably contributed to the Brazilian flora, especially in the taxonomy of Arecaceae and Orchidaceae (Mori \& Ferreira, 1987). With respect to Aristolochia, Barbosa Rodrigues described four taxa, $A$. alpestris, A. chrysochlora, A echinata, and A. silvatica. Barbosa Rodrigues did not designate type specimens for these species, but he cited the collecting localities and phenology (Toscano de Brito, 2013). His collections were housed at the former "Museu Botânico do Amazonas", but they were lost after the Museum was closed in 1890 (Mori \& Ferreira, 1987), including the potential type specimens, most of which did not have duplicates elsewhere.

Barbosa Rodrigues was a skilled botanical illustrator and, through watercolour or in line drawings, he drawed the species described by himself. Here, we designate three of them as lectotypes of $A$. chrysochlora, A. echinata, and A. silvatica, respectively. In addition, $A$. chrysochlora and A. echinata

\section{Resumen}

Freitas, J., Alves-Araújo, A., \& Favio González, F. 2016. Lectotipificaciones y sinónimos nuevos de Aristolochia (Aristolochiaceae) publicados por el botánico brasileño João Barbosa Rodrigues. Anales Jard. Bot. Madrid 73(1): e030.

Se discuten las tipificaciones de los nombres Aristolochia chrysochlora Barb. Rodr., A. echinata Barb. Rodr. y A. silvatica Barb. Rodr. (Aristolochiaceae). Se designan como lectotipos las ilustraciones originales hechas por J. Barbosa Rodrigues y publicadas junto a los protólogos respectivos. Además, $A$. chrysochlora y A. echinata se subordinan a A. arcuata Mast. y A. tamnifolia (Klotzsch) Duch., respectivamente. De estas dos últimas especies se designan también los lectotipos.

Palabras clave: Brasil, João Barbosa Rodrigues, lectotipificación, Piperales.

are subordinated as new synonyms of $A$. arcuata Mast. and A. tamnifolia (Klotzsch) Duchartre, respectively.

\section{TYPIFICATIONS AND NEW SYNONYMS}

Barbosa Rodrigues (1891a) described A. chrysochlora and $A$. silvatica, both based on specimens collected in the Amazonian region of Brazil. Aristolochia chrysochlora was collected in Tarumã, by the Rio Negro, and A. silvatica in Cachoeira Grande, near Manaus. Given that there are no traceable type specimens for these taxa, it is necessary to designate lectotypes, following the Art. 9.11 of the Code of Nomenclature for Algae, Fungi, and Plants (McNeill \& al., 2012). Therefore, published illustrations for these species (Barbosa Rodrigues, 1891b) are designated here as lectotypes. The original illustration of $A$. chrysochlora chosen as the lectotype shows a leaf that somehow does not represent the typical sagittate or hastate leaf shape found in A. arcuata; however, Barbosa Rodrigues's (1891: 71) description clearly states that it has "foliis sagittatis".

Aristolochia arcuata was described by Masters (1878: 101) from three syntypes: [Brazil] "Habitat in prov. Minas Geraës ad Lagoa Santa", E. Warming s.n.; "in prov. Rio de Janeiro", L. Riedel \#196, and "in Brasilia occidental", Tamberlik s.n. We designate as lectotype the specimen E. Warming s.n., collected in Lagoa Santa on 16th February 1864 (C 10006604). This specimen is the most complete, it clearly shows the diagnostic characters of the species, and 
it has several black and white and colour illustrations and original handwritten annotations.

Aristolochia echinata was described and illustrated by Barbosa Rodrigues (1896). The original description was based on a flowering specimen cultivated at São Pedro do Itabapoana (State of Espírito Santo, Brazil). Also in this case, no type specimen was found, either at the herbarium of the Jardim Botânico do Rio de Janeiro nor in any other institution. In accordance with the Art. 9.1 of the Code (McNeill \& al., 2012), the lectotypification of $A$. echinata is required. Thus, we designate the illustration made by Barbosa Rodrigues for the protologue as lectotype.

After detailed comparisons between the diagnosis, type specimens and illustrations of putatively related species, we came to the conclusion that Aristolochia echinata is conspecific with Aristolochia tamnifolia (Klotzsch) Duch. Therefore, $A$. echinata is here designated as a new synonym of $A$. tamnifolia. Detailed photographs of the latter species are provided in Freitas \& al. (2016).

1. Aristolochia arcuata Mart., Fl. Bras. 4(2): 101, tab. XXII (2) (1875).

TYPE: [Brazil.] Habitat in prov. Minas Geraës ad Lagoa Santa, E. Warming s.n., 16 Feb 1864, (lectotype, here designated: C 10006604).

A. chrysochlora Barb. Rodr., Vellosia ed. 2, 1: 71, tab. XXIII fig. A (1891). TYPE: [Icon] (lectotype, here designated: Barb. Rodr., Vellosia ed. 2, 1, tab. XXIII fig. A (1891).

2. Aristolochia silvatica Barb. Rodr., Vellosia ed. 2, 1: 70, tab. XXIII fig. B (1891).

TYPE: [Icon] (lectotype, here designated: Barb. Rodr., Vellosia ed. 2, 1, tab. XXIII fig. B (1891).

3. Aristolochia tamnifolia (Klotzsch) Duch. in DC., Prod. 15(1): 448 (1896). Howardia tamnifolia Klotzsch, Monatsber. Königl. Preuss. Akad. Wiss. Berlin 1859: 620 (1859).

TYPE: [Brazil.] "Hab. in Brasilia", Sellow \#146 (holotype: B n.v., lost; lectotype, here designated: BR; isolectotypes: $\mathrm{K}, \mathrm{P}$ ).

A. echinata Barb. Rodr., Pl. Jard. Rio Janeiro 5: 9, tab. III (1896).

TYPE: [Icon] (lectotype, here designated: Barb. Rodr., Pl. Jard. Rio Janeiro 5, tab. III fig. A (1896).

\section{ACKNOWLEDGEMENTS}

The first author wishes to thank CAPES for its financial support. Thanks also to Elton John de Lírio and the anonymous reviewers for their valuable contributions to this work.

\section{REFERENCES}

Barbosa Rodrigues, J. 1891a. Eclogae plantarum novarum. Vellosia ed. 2, 1: 1-89.

Barbosa Rodrigues, J. 1891b. Estampas, Botanica. Vellosia ed. 2, 3: 1-90.

Barbosa Rodrigues, J. 1896. Plantas novas cultivadas no Jardim Botânico do Rio de Janeiro, vol. 5. Typ. Leuzinger, Rio de Janeiro.

Barros, F. de, Araújo, A.A.M. \& Freitas, J. 2015. Aristolochiaceae. In: Campostrini, R., Zappi, D., \& Castro Souza, V. (coords.), Lista de Espécies da Flora do Brasil. Jardim Botânico do Rio de Janeiro. http:// www.floradobrasil.jbrj.gov.br/jabot/floradobrasil/FB103040.

Duchartre, P. 1864. Aristolochiaceae. In: De Candolle, A.P. Prodromus Systematis Naturalis Regni Vegetabilis 15(1): 420-499.

Freitas, J., Lirio, E.J., González, F. \& Alves-Araújo, A. 2016. Aristolochia zebrina sp. nov. (Aristolochiaceae) from southeastern Brazil. Nordic Journal of Botany 34(1): 54-59. http://dx.doi.org/10. $1111 /$ njb.00928.

González, F. 2000. A new species of Aristolochia (Aristolochiaceae) from Bahia, Brazil. Novon 10: 371-374. http://dx.doi.org/10.2307 13392989.

González, F. 2011. A new pseudostipule-bearing species of Aristolochia (Aristolochiaceae) from Bahía and Espírito Santo, Brazil. Brittonia 63: 430-435. http://dx.doi.org/10.1007/s12228-011-9184-2.

Masters, M.T. 1875. Aristolochiaceae. In: Martius, C. F. P. von (ed.), Flora Brasiliensis 4(2): 76-114, tab. 17-26. Frid. Fleischer, Leipzig.

McNeill, J., Barrie, F.R., Buck, W.R., Demoulin, V., Greuter, W., Hawksworth, D.L., Herendeen, P.S., Knapp, S., Marhold, K., Prado, J., Prud'homme van Reine, W.F., Smith, G.F., Wiersema, J.H. \& Turland, N.J. 2012. International code of nomenclature for algae, fungi, and plants (Melbourne Code): adopted by the eighteenth international botanical congress, Melbourne, Australia, July 2011. Regnum Vegetabile 154: $1-208$.

Mori, S.A. \& Ferreira, F.C. 1987. A distinguished Brazilian botanist, João Barbosa Rodrigues (1842-1909). Brittonia 39(1): 73-85. http://dx.doi. org/10.2307/2806978.

Toscano de Brito, A.L.V. 2013. Lectotypification of Aristolochia alpestris (Aristolochiaceae) and Monostychosepalum monanthum (Burmanniaceae): Two obscure Brazilian species described by João Barbosa Rodrigues (1842-1909). Harvard Papers in Botany 18(2): 237-239. http://dx.doi.org/10.3100/025.018.0216. 